\title{
Principles, Procedures and Policies Adopted in Improvement and Widening of Roads (Sh-88)
}

\author{
Rami Reddy Madhuri, Gandham Prasanna, Venu Malagavelli, D. Prince Kamal Kiran
}

\begin{abstract}
Road widening is the solution for the problem of traffic density and road accidents, transportation infrastructure is the ever green problem facing all over the world, as day by day with the growth of economic status the people are switched to use four wheelers from two wheeler vehicles, the roads at present are mean for the capacity of the present situation, as the traffic density increases the improvements in road infrastructure and widening of roads are required. We concentrated on the different road widening problems and solutions carried out and mainly focused on the Mysore Bantwal Road (SH-88). The need of this research is to design Road transport model to ensure safe and effective moment of traffic. We even discussed different principles, policies and procedures of the design standards and guidelines. The major aim is to reduce economic losses and to improve capabilities for overlay design that are provided to meet today's highway traffic needs. Finally we used IIT PAVE software for calculating fatigue and rutting performance criteria.
\end{abstract}

Keywords: Widening, Transportation, Infrastructure, Roads, Traffic density.

\section{INTRODUCTION}

Transportation Infrastructure shows the economic growth and status of country's development. The designs and structures of Road Transport Infrastructure reduces the Road accidents and traffic Jams. The growths of four wheelers are increasing day by day, to face the present situations and estimation of feature, the solution is the Road Widening, for the improvement of traffic performance [1].

It is necessary to conduct the research and Analysis for road widening; the factors that effect on this concept are traffic density, present road wide, planned road wide, pros in the road design, and requirements for structure change. For the Road widening, the existing traffic volume study carried out and compared with design standard. The capacity, Jam density, Average daily traffic is calculated for the widening

Revised Manuscript Received on February 05, 2020.

* Correspondence Author

Rami Reddy Madhuri, Department of Civil Engineering, Institute of Aeronautical Engineering, Dundigal, Hyderabad, India.

E-mail: xyz1@blueeyesintlligence.org

Gandham Prasanna, Department of Civil Engineering, Institute of Aeronautical Engineering, Dundigal, Hyderabad, India.

E-mail: prasannagandham25@gmail.com

Dr. M. Venu, Professor department of Civil Engineering, Institute of Aeronautical Engineering, Dundigal, Hyderabad, India.

E-mail: venu.bits@gmail.com

D. Prince Kamal Kiran*, Research Scholar department of Civil Engineering, Lovely Professional University, Punjab, India.

E-mail: princekamal.kiran@gmail.com

(C) The Authors. Published by Blue Eyes Intelligence Engineering and Sciences Publication (BEIESP). This is an open access article under the CC BY-NC-ND license (http://creativecommons.org/licenses/by-nc-nd/4.0/) and strengthening of roads. The widened Portion is calculated based on the mechanistic flexible pavement design carried out as per IRC 37-2012 and design is intended with flexibility of the pavement, Pavement Evaluation and strengthening of pavement. Pavements are the key elements of infrastructure of a country, whose functions are to promote transportation. Flexible pavements undergo functional deterioration as well as structural deterioration simultaneously [2].

The rate of structural deterioration of flexible pavement depends on several factors such as

- $\quad$ The stability of the entity provident structure and the component layers.

- Efficiency functions of the pavement drainage system and sensitivity of the climate.

The unexpected enclosure development in the given region based on the traffic loads on the arterial roads. Fast growth in industries and urban areas has made to increase traffic and excessive usage of the roads. The weakening accumulates with the passage of time and results in failure of pavement structure. The failure is of structural type, if the pavement fails to carry design loads. It is of functional type, if it does not give a smooth riding surface, which in turn increases vehicle operation. The performance evaluation of a road can cover many aspects including evaluation of road surface condition. The maintenance engineering should therefore carryout structural evaluation studies periodically, based on the design period time, under given static and dynamic loads once the pavement is evaluated [3].

\section{LITERATURE SURVEY}

In 2010 Rokade et.. al.., studied on structural and functional evaluation of 4 national and 1 state high ways. The structural evaluation pavement is based on Benkelman Bean Technique to measure the residual \& rebound deflections of the pavement structure. Benkelman beam deflection performance test can be done based on standard specification for high performance and standard functional structural evaluations [4]. In 2015 Betten Singh et.. al.., analyzed the traffic flow in Bangalore and Mysore cities of India are a mixed traffic characteristics. The traffic congestion is the common problem; most of the roads are congested and operate in low level of service[5]. To improve the performance operation of the urban road network by proposing the proper alternatives to enhance the traffic capacity a methodology is designed to achieve a complete methodology for analyzing the mixed traffic flow is analyzed. In 2013 Indrajit ghosh et.. al., proposed methods related to Performance evaluation based on the capacity analysis for various highway facilities. 
The capacity analysis procedure, In general is expressed as performance of a highway in terms of level of service (LOS). Evaluating the performance of the two-lane roads is based on IRC: 64-1990 provides guidelines. The Highway Capacity Manuals (HCM) of other developed countries are used for reference, which summaries the evolution of research on determining the LOS of two-lane roads [6].

\section{GEOMETRIC DESIGNS}

\section{A. Terrain Classification}

The slope of the country classifies and specifies terrain across the specified area. The terrain is very important parameter for classification of terrain short isolated stretches of varying among these terrain should not be considered

Table 1: Terrain - Classification Cross Slope in \%

\begin{tabular}{|c|c|}
\hline Terrain & $\begin{array}{c}\text { Classification Cross } \\
\text { Slope in \% }\end{array}$ \\
\hline Plain & $0-10$ \\
\hline Rolling & $10-25$ \\
\hline Mountainous & $25-60$ \\
\hline Steep & $>60$ \\
\hline
\end{tabular}

\section{B. Design Speed}

Design Speed is a primary criterion for formative all geometric features of horizontal and vertical alignment. The design speeds for the roads particularly designed and paying attention on village roads [8] should be taken as given in table below:

Table 2: Road Classification - Design Speed

\begin{tabular}{|c|c|c|c|c|c|c|c|c|}
\hline \multirow{3}{*}{ 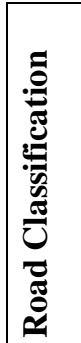 } & \multicolumn{8}{|c|}{ Design Speed (Km/h) } \\
\hline & \multicolumn{2}{|c|}{$\begin{array}{c}\text { Plain } \\
\text { Terrain }\end{array}$} & \multicolumn{2}{|c|}{$\begin{array}{l}\text { Rolling } \\
\text { Terrain }\end{array}$} & \multicolumn{2}{|c|}{$\begin{array}{c}\text { Mountainous } \\
\text { Terrain }\end{array}$} & \multicolumn{2}{|c|}{$\begin{array}{c}\text { Steep } \\
\text { Terrain }\end{array}$} \\
\hline & 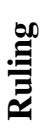 & $\dot{\Xi}$ & 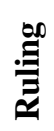 & $\dot{\Sigma}$ & $\stackrel{\mathscr{0}}{\Xi}$ & $\dot{\dot{E}}$ & $\stackrel{\infty 00}{\Xi}$ & $\dot{\dot{B}}$ \\
\hline ODR & 65 & 50 & 50 & 40 & 30 & 25 & 25 & 20 \\
\hline
\end{tabular}

Ruling design speed should be the guiding criterion for the purpose of geometric design. Minimum design speed may, however, be adopted where site condition and cost does not permit a design based on "Ruling Design Speed" [9].

\section{Carriage Width}

The Width of the carriage way depends on the Predicated traffic volume and traffic capacity of each line.

Table 3: Classification of Carriage width of way.

\begin{tabular}{|c|c|}
\hline Classification & $\begin{array}{c}\text { Width of carriage } \\
\text { way }\end{array}$ \\
\hline Single lane & $3.75 \mathrm{~m}$ \\
\hline Two lanes without raised kerbs & $7.0 \mathrm{~m}$ \\
\hline Two lanes with raised Krebs & $7.5 \mathrm{~m}$ \\
\hline Intermediate carriage way & $5.5 \mathrm{~m}$ \\
\hline Multilane pavements & $3.5 \mathrm{~m}$ per lane \\
\hline
\end{tabular}

\begin{tabular}{|l|c|}
\hline Plain and rolling terrain & $7 \%$ \\
\hline Snow bound area & $7 \%$ \\
\hline Hilly area but not snow bound & $8-10 \%$ \\
\hline
\end{tabular}

\section{COMPONENTS OF FLEXIBLE PAVEMENT}

This In this type of pavement, there would be grain to grain transfer of load. It consists of fore layers namely Sub-grade, Granular Sub base (GSB), Wet Mix Macadam (WMM), Dense Bitumen Macadam (DBM) and Bituminous Concrete (BC). By considering the traffic load for designed years, rutting criteria, fatigue criteria, we calculate the load acting on the pavement for designing. Rutting and fatigue are some of the failures which occur in the corresponding sub base and bituminous course. Failure may occur due to loads, unforeseen site conditions, improper material selection, inadequate layer dimensions etc. Hence to prevent failure, specifications are to be followed [10]. 


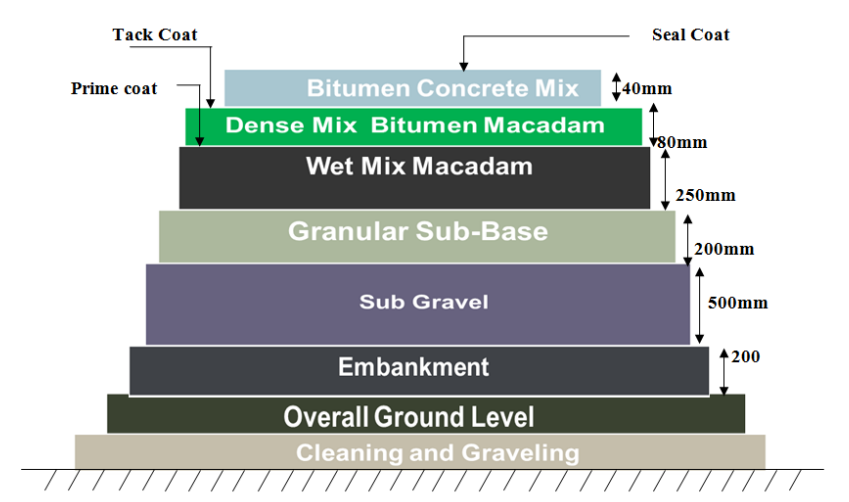

Figure 1: Different layers of flexible pavement

\section{LAB TESTS}

\section{Tests on Sub-GradelSoil}

A. free swell index:

$>$ Take $500 \mathrm{~g}$ of sample and oven dry it at a temperature $\left(100^{\circ} \mathrm{C}-110^{\circ} \mathrm{C}\right)$ for 24 hours.

$>$ Sieve the oven dried sample through IS Sieve $425 \mu$.

$>$ Take the sample passing through that sieve in two flakes of $100 \mathrm{ml}$ capacity, a quantity of $10 \mathrm{~g}$ in each flask.

$>$ Add $100 \mathrm{ml}$ of distilled water in first containerand $100 \mathrm{ml}$ of kerosene in another container.

> Stir the sample well by stirrer to remove the entrapped air in it and allow the soil to swell and settle by keeping the flasks ideal for $24 \mathrm{hrs}$.

$>$ Note the level of soil in both flasks after 24 hrs.

$$
\text { Free swell index }=\frac{V_{d}-V_{k}}{V_{K}} \times 100
$$

Where

$V_{d}=$ volume of soil specimen read from the graduated cylinder containing distilled water.

$V_{k}=$ volume of soil specimen read from the graduated cylinder containing kerosene.

\section{B. Casagrandes Test}

This test is done to know the liquid limit of the soil sample. Procedure:

$>$ The Casagrande's apparatus is set such that the number of shocks is ' 0 ' at the reading and is checked whether the instrument shows a unit for every one shock.

$>$ The soil is mixed with unknown amount of water thoroughly using spatula uniformly. Using spatula, the soil is applied in the cap of the Casagrande's apparatus up to $1 \mathrm{~cm}$ level. This $1 \mathrm{~cm}$ level is checked with spatula.

$>$ With the help of grooving tool, the paste in the brass cap is divided along the diameter of cup by holding the tool normal to the surface and drawing it firmly across the cup.

$>$ The handle of Casagrande's apparatus is operated by turning it at the constant rate until the bottom of the grove (approx. 12mm). The numbers of bows or shocks are noted and the representative slice of soil is collected using spatula width wise from one edge to the other edge.

$>$ The collected soil is kept in moisture container and weighed. Also, the empty weight of container is noted. Now the soil is put for drying.

$>$ After drying, the container is weighed and noted. This process is done for different water contents of soil [12].

\section{Plastic Limit Test}

This test is conducted to find the plastic limit of soil sample. $>$ The soil sample is mixed with sufficient amount of distilled water on marble/glass plate to make it plastic enough to be shaped in to a ball.

$>$ Some sample is taken and taken and made into a ball. That ball is rolled on a glass plate with hand by applying sufficient pressure. It is rolled into a thread of uniform diameter throughout its length.

$>$ When the diameter of the thread has decreases to $3 \mathrm{~mm}$, the specimen is kneaded together and rolled again. The process is continued until the thread just crumbles at $3 \mathrm{~mm}$ diameter.

$>$ The crumbled soil thread is taken in to the moisture container and water content is determined.

$>$ The test is repeated for different water contents in the soil [13].

This water content is noted as plastic limit for given soil sample.

\section{California Bearing Ratio (Cbr) Test}

$>$ This test is used to find the CBR value represents the bearing strength of soil. It is based on the normalized values over a lot of experiments conducted on crushed aggregate powder by California Highway Department.

$>$ Specimen, passing through $20 \mathrm{~mm}$ sieve, in the mould is subjected to four days soaking. Load is applied in the cylindrical plunger of $5 \mathrm{~cm}$ diameter so that the penetration rate is $1.25 \mathrm{~mm} / \mathrm{minute}$.

$>$ The loads for $0,0.5,1,2,2.5,3,4,5,7,10$ and $12.5 \mathrm{~mm}$ penetration are recorded.

$>$ A graph is drawn between load and penetration values. The load values corresponding to $2.5 \mathrm{~mm}$ (P2.5mm) and $5 \mathrm{~mm}(\mathrm{P} 5 \mathrm{~mm})$ penetration values are noted.

$>$ Normally the CBR value at $2.5 \mathrm{~mm}$ penetration is higher than that at $5 \mathrm{~mm}$ penetration and higher value is reported as CBR value of the soil [14].

$$
\operatorname{CBR}(\%)=\frac{P_{2.5 \text { or } 5 \mathrm{~mm}}}{P_{\text {standard } 2.5 \text { or } 5 \mathrm{~mm}}} \times 100
$$

Where

Standard $\mathrm{P}_{2.5 \mathrm{~mm}}=1370 \mathrm{~kg} \quad$ Standard $\mathrm{P}_{5 \mathrm{~mm}}=2035 \mathrm{~kg}$

\section{EXPERIEMENTAL ANALYSIS}

The overlay design and pavement thickness design are checked for performance criteria using IIT-PAVE software developed by IIT-Kharagpur which is given along with IRC: 37-2012 [15].

The software required input is like as Elastic Modulus of five layers in $\mathrm{MPa}$, bituminous layer, granular layer (WBM, GSB ...etc.) and Subgrade. Poisson's ratio of all the five layers \& thickness in mm. The thickness of subgrade layer is not required it is considered infinite, all parameters given in below table with value to be used in design and analysis [16]. 
Table 5: Data to be used in analysis

\begin{tabular}{|c|c|c|c|c|}
\hline $\begin{array}{c}\text { Sr. } \\
\text { No. }\end{array}$ & Layer & $\begin{array}{c}\text { Modulus in } \\
\text { Mpa }\end{array}$ & $\begin{array}{c}\text { Poisson's } \\
\text { ratio }\end{array}$ & $\begin{array}{c}\text { Thickness in } \\
\text { mm }\end{array}$ \\
\hline 1 & $\begin{array}{c}\text { Bituminous } \\
\text { layer }\end{array}$ & 3000 & 0.35 & 155 \\
\hline 2 & Base layer & 171.0658 & 0.35 & 250 \\
\hline 3 & $\begin{array}{c}\text { Sub base } \\
\text { layer }\end{array}$ & 130.2280 & 0.35 & 300 \\
\hline 4 & Sub grade & 50 & 0.35 & - \\
\hline
\end{tabular}

Wheel load is required to be input as standard load 40000N for single wheel assembly, for dual wheel set require $20000 \mathrm{~N}$ same is adopted. The tyre pressure is considered 0.56 MPa. The Point of analysis has to be given to know strain developed at critical location as discussed in fatigue and rutting model [17].

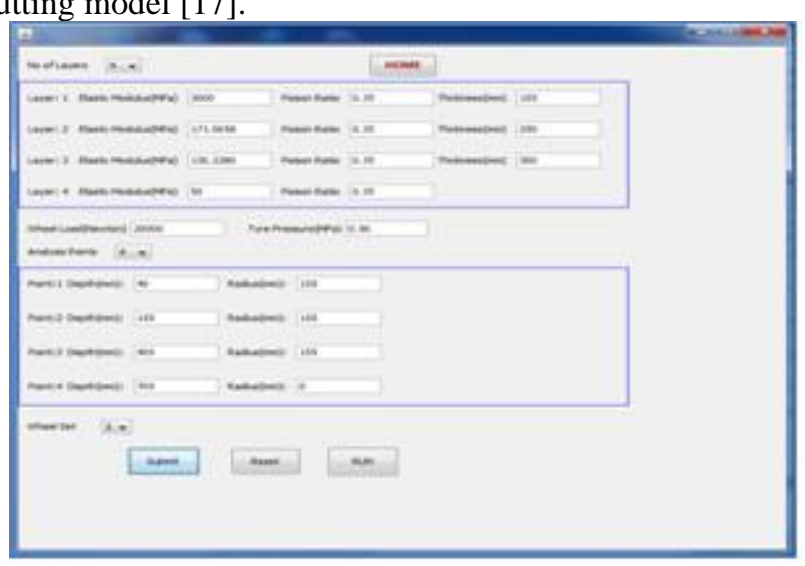

Figure2: IIT PAVE input screen

For the above input the output available in strain value at different location. Point of consideration is epT means tensile strain and epZ means vertical strain. Which shown as in below figure.

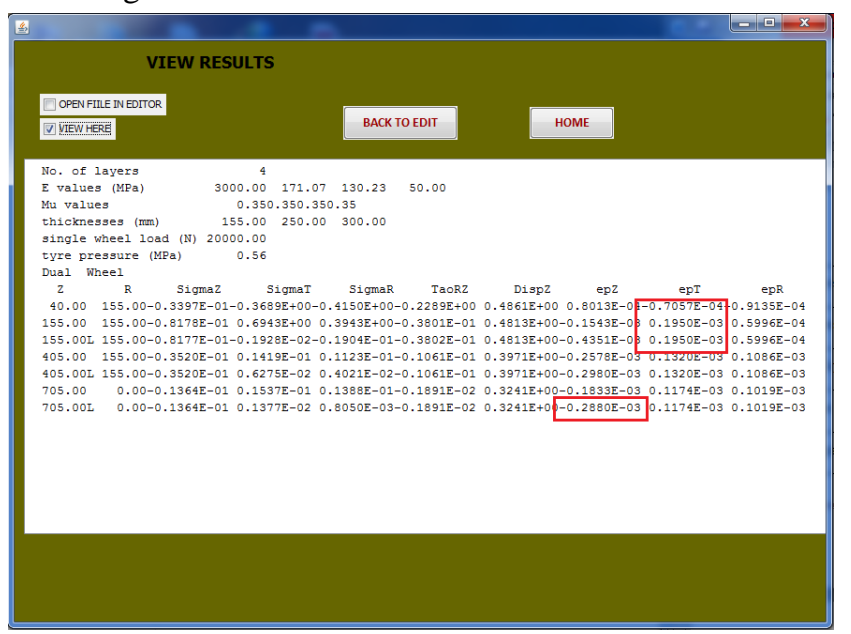

i) Allowable Horizontal Tensile Strain in Bituminous Layer is 155 x 10-6for VG 40 mixes based on fatiguemodel.

ii) Allowable Vertical Compressive Strain on Subgrade is 371 x 10-6 from the rutting-model.

From the IIT PAVE output screen result:

i) Horizontal tensile strain in bituminous layer is $195 \times 10-6>$ $155 \times 10-6$, This is not safe in horizontal tensile strain, so it need to increase thickness of bituminous layer than check. ii) Vertical compressive strain on subgrade is $288 \times 10-6<$ $371 \times 10-6$, this is safe. Increase bituminous layer thickness $195 \mathrm{~mm}$ from $155 \mathrm{~mm}$, and base layer $250 \mathrm{~mm}$, sub-base layer $300 \mathrm{~mm}$ and all other parameters are as it is. This design is checked below IIT PAVE software.

\section{CONCLUSION}

It is observed from data that average daily traffic (ADT) in $\mathrm{PCU} /$ day is more than the IRC recommended for capacity per day of 2 lane for plain ruralroad.

Average daily traffic (ADT) on Mysore -Bantwal state highway 88is 25,843 PCU/day, it is more than 15,000 PCU/day of IRC recommended for capacity per day of 2 lane plain rural road from which it has been justified that widening is required on the selectedstretch.

Mechanistic pavement design for widening is also proposed which will be having $745 \mathrm{~mm}$ of overall depth with surface layer of $195 \mathrm{~mm}$, base layer $250 \mathrm{~mm}$ and sub-base layer 300mm.

It has been found that 4 sections are having poor surfaces (1secton $=1 \mathrm{~km}$ ) from the surface condition survey, and structural evaluation also has conducted using Benkelman beam deflection test at poor section within $4 \mathrm{~km}$ and found the characteristic deflection.

Overlay thickness at each section (total 4 kilometer) is calculated in 3 alternate designs like BC/DBM, DBM and $\mathrm{BM}$ are i) 35/40, 85, 120 ii) 35/40, 75,105 iii) 30/40, 70, 100 iv) 35/55, 90, 125respectively.

In mechanistic pavement design fatigue strain calculated as per multi-layer elastic theory using IIT PAVE software is 152 micro at bottom of bituminous layer, it is lower than 155 micro strain calculated as per performance model for $90 \%$ reliability so pavement design is safe in fatigue failure.

Rutting strain calculated as per multi-layer elastic theory using IIT PAVE software is 238 micro at top of sub grade, it is lower than 371 micro strain calculated as per performance model for $90 \%$ reliability so pavement design is safe in rutting failure.

\section{REFERENCES}

1. Kharola, Pradeep \& Tiwari, Geetam \& Mohan, Dinesh. (2010). Traffic Safety and City Public Transport System: Case Study of Bengaluru, India. Journal of Public Transportation. 13. 10.5038/2375-0901.13.4.4

2. Srinivasa Kumar, R..(2018) Pavement Evaluation and Maintenance Management System.

3. Avinash, N. \& H N, Vinay \& Prasad, D. \& Dinesh, S. \& Dattatreya, J. (2014). Performance Evaluation of Low Volume Flexible Pavements A Case Study. 69-78. 10.1061/9780784413586.007.

4. Busetty, Subramanyam \& Aravind, S. \& Kumar, R.. (2017). Functional and structural evaluation of a road pavement. International Journal of Civil Engineering and Technology. 8. 1299-1305.

5. Musunuru, A., Wei, R., \& Porter, R. J. (2017). Predicting Day and Night Traffic Volumes on Rural Roads for Statistical Road Safety Modeling. Transportation Research Record, 2659(1), 192-203.

6. Boora, Amardeep \& Ghosh, Indrajit \& Chandra, Satish. (2016). Assessment of Level of Service Measures for Two-Lane Intercity Highways under Heterogeneous Traffic Conditions. Canadian Journal of Civil Engineering. 44. 10.1139/cjce-2016-0275.

7. H T, Basavarajappa \& K.N, Pushpavathi \& M.C. Manjunatha, Dr. (2015). LAND USE / LAND COVER CLASSIFICATION ANALYSIS AND SOIL CONSERVATION IN PRECAMBRIAN TERRAIN OF CHAMARAJANAGARS DISTRICT, KARNATAKA INDIA USING GEOMATICS APPLICATION. International Journal of Science, Engineering and Technology, I.F-3.25. 10.2348, Vol.3. 739-747. 
8. Srikiran, S \& Kumar, S \& Venkatasubramanian, C \& Muthu, D. (2018). Geometric Design of Highways for Accommodation of More Traffic Volume with Increased Design Speed. International Journal of Engineering \& Technology. 7. 137. 10.14419/ijet.v7i3.12.15903.

9. Amiridis, Kiriakos \& Psarianos, Basil. (2015). 3-D ROAD DESIGN BY APPLYING DIFFERENTIAL GEOMETRY. MATHEMATICAL DESIGN AND TECHNICAL AESTHETICS. 3. 46-75.

10. Shalkamy, Amr \& Said, Dalia \& Radwan, Laila. (2015). Influence of Carriageway Width and Horizontal Curve Radius on Passenger Car Unit Values of Two-lane Two-way Rural Roads. Civil and Environmental Research. 7.

11. Pereira, Paulo \& Pais, Jorge. (2017). Main flexible pavement and mix design methods in Europe and challenges for the development of an European method. Journal of Traffic and Transportation Engineering (English Edition). 4. 10.1016/j.jtte.2017.06.001.

12. Haigh, Stuart. (2015). Consistency of the Casagrande Liquid Limit Test. Geotechnical Testing Journal. 39. 10.1520/GTJ20150093.

13. Haigh, Stuart \& Vardanega, Paul \& Bolton, Malcolm. (2013). The plastic limit of clays. Géotechnique. $63.435-440$ 10.1680/geot.11.P.123.

14. Katte, Valentine \& Mfoyet, Souleyman \& Manefouet, Bertille \& Wouatong, Armand \& Bezeng, Lawrence. (2018). Correlation of California Bearing Ratio (CBR) Value with Soil Properties of Road Subgrade Soil. Geotechnical and Geological Engineering. 10.1007/s10706-018-0604-x.

15. Bhagat, Kunal \& Hadial, Chetan \& Solanki, Ujjval. (2015). " Mechanistic Design of Overlay Based on Benkelman Beam Deflection Technique " (A Case Study of Rajkot-Morbi State Highway-24).

16. Kleiziene, Rita \& Vaitkus, Audrius \& Cygas, Donatas. (2016). Influence of asphalt visco-elastic properties on flexible pavement performance. The Baltic Journal of Road and Bridge Engineering. 11. 313-323. 10.3846/bjrbe.2016.36.

17. Maaty, Ahmed. (2012). Fatigue and rutting lives in flexible pavement. Ain Shams Engineering Journal. 3. 367-374. 10.1016/j.asej.2012.04.008

\section{AUTHORS PROFILE}

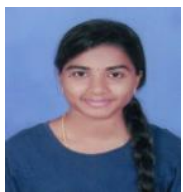

Rami Reddy Madhuri, is B.Tech Scholar at Department of Civil Engineering, Institute of Aeronatical Engineering, Dundigal, Hyderabad. Her Research areas are Structures, Building Construction, Transportantion and Roads, Waste water usage and Water management.

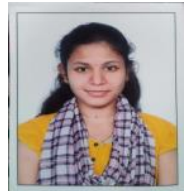

Gandham Prasanna, is a B.Tech Scholar at Department of Civil Engineering, Institute of Aeronatical Engineering, Dundigal, Hyderabad. Her research areas are Transporation and Roads, Building and Construction, civil and water works.

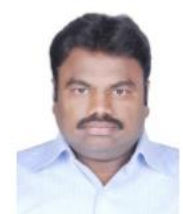

Venu Malagavelli, working as Professor in the Department of Civil Engineering, Institute of Aeronautical Engineering, Dundigal, Hyderabad. He obtained $\mathrm{PhD}$ and ME from BITS Pilani and B.Tech from JNTUCEH, Hyderabad. He Published more than 30 papers in International and national Journals and conferences. His area of research is development of new concrete using industrial waste materials. He is a life member of IEI, ICI, IIBE, ISTE etc. He received travel grants from DST and CICS.

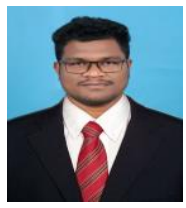

D. Prince Kamal Kiran*, Research Scholar department of Civil Engineering, Lovely Professional University, Punjab, India and He is at Present working as Assistant Professor at Warangal Institute of Technology and Science, Warangal. His Research areas are Building Construction, Town Planning, Water Works, Roads and Transportation. 